\title{
Identifying an Improved Jute Variety Preferring Physico-chemical Properties
}

\author{
Mubarak Hossen", Ayesha Khatton, Fa Dilruba \\ Bangladesh Jute Research Institute, Manik Mia Avenue, Dhaka, Bangladesh
}

Email address:

mbmubarak24@gmail.com (M. Hossen)

\section{To cite this article:}

Mubarak Hossen, Ayesha Khatton, Fa Dilruba. Identifying an Improved Jute Variety Preferring Physico-chemical Properties. American Journal of Nanosciences. Vol. 5, No. 4, 2019, pp. 56-58. doi: 10.11648/j.ajn.20190504.15

Received: October 29, 2019; Accepted: November 27, 2019; Published: December 5, 2019

\begin{abstract}
There are so many fibres, but not all of them are textile. Textile materials are generally soft, flexible, and capable of being transformed into desired shapes without resistance and durable over a reasonable period of wear. Jute -the Golden fibre of Bangladesh is used widely for various purposes. For the assessment of fibre quality of three types of jute fibre e.g. newly released jute variety-72, bleached fibre and variety O-9897 were considered for the analysis of physical properties (Reed jute fibre length, Brightness index, Whiteness index, Bundle strength and Fineness index) and chemical analysis (Cellulose, Hemicellulose, Lignin, Ash content, Fat/Oil content, Oil content in jute seed, Pectin content and safonification value) under the present study.Some field level morphological information was taken as quality contributing characteristics. The study was conducted at the Chemistry Division, Textile Physics Division and Pilot Plant and Processing Division of Bangladesh Jute Research Institute, Dhaka, Bangladesh during 2017-2019. The assessment of physico-chemical properties of the variety O-72 was blue seeded with lower percentage of oil content than naturally brown seeded but saponification value was higher, Brightness (22.04\%), fineness (36.26\%) and bundle strength $(06.20 \mathrm{lb} / \mathrm{mg})$ index were very much comparable to bleached jute samples using $6 \%$ hydrogen peroxide. Cellulose content was $65.68 \%$ as well as lignin and hemicelluloses content were $13.95 \%$ and $17.94 \%$ respectively which were more prominent than O-9897 varieties of jute fibres.
\end{abstract}

Keywords: Brightness, Whiteness, BundleStrength, Cellulose and Lignin

\section{Introduction}

Jute is not only a major textile fibre but also a raw material for non- traditional and value added non-textile products. Jute is used extensively in the manufacture of different types of traditional packaging fabrics, manufacturing hessian, sacking, carpet backing, mats, bags, tarpaulins, ropes and twines. Recently jute fibres are used in a wide range of diversified products: decorative fabrics, chic-saris, salwar kamizes, soft luggage's, footwear, greeting cards, molded door panels and other innumerable useful consumer products. Supported by several technological developments today jute can be used to replace expensive fibres and scare forest materials. The quality of jute fibre is very much important for the development of jute products (diversified jute products). Jute is a lignocellulosic bastfibre. It consists of cellulose cemented by non-cellulosic materials i.e., pectin, lignin, hemicellulose etc. The usual composition of chemical constituents in jute fibre is alpha cellulose (58-63\%), hemicellulose (21-24\%), lignin (12-14\%), wax (0.4-0.8\%), pectin $(0.2-0.5 \%)$, ash (0.6-1.2) and traces of other coloring materials [1]. It was reported that hemicellulose and lignin act as cementing materials for small ultimate cell of jute fibre and partial removal of lignin and hemicellulose makes fibre soft and more flexible [2] The percentages of different chemicals in jute fibre are responsible and influenced the quality of fibre significantly. Brightness and whiteness index of jute fibre is very important property for jute grading and end uses. For upgrading the jute fibre different types of chemicals and finishing treatment has been carried out but it is very costly. Jute fibres are composed primarily of the plant materials i.e. cellulose and lignin. It is thus a lignocellulossicfibre that is partially a textile fibre. Jute fibres are lignocellulosic [3] and thus the secondary walldevelopment of the sclerenchymaticfibre cells involves deposition of lignin over the cellulose matrix [4-5]. Presence of lignin in the fibre cell wall makes it impermeable andresistant to microbial degradation [6]. In these dicotyledonous plants, 
thecommercial fibres are sclerenchyma cells with copious secondary wall thickening [7-8]. The lignin content of the fibre cell wall varies from species to species. While it is around $15 \%$ injute, it is less than 5\% in flax and ramie [9-10]. Attentionis always given to the development of improved variety of jute. Based upon the information [11-14]for increasing whiteness andbrightness of jute fibre different bleaching treatments have been carried out. If a new jute variety isinvented where there is no need of any bleaching treatment of diversified uses, that type of varietyshould be very valuable. Present work indicates to find out an improved jute variety which will bemostly comparable with the bleached jute fibre.

\section{Materials and Methods}

The study was conducted at the Chemistry Division, Textile Physics Division and Pilot Plant and Processing Division of Bangladesh Jute Research Institute, Dhaka, Bangladesh during 2017-2019. The matured jute fibre of the variety O-72 was collected from the Agricultural Wing of Bangladesh Jute Research Institute (BJRI). For proper investigation of comparative study, jute fibre of variety $\mathrm{O}$ 9897 was also taken ad control jute sample.

\subsection{Physical Parameters}

Reed fibre length, brightness/whiteness index, bundle strength fineness etc. were determined according to standard methods followed by BJRI. Bundle strength test: To measure bundle strength a bundle of fibre of each sample was combed to make the fibres parallel and suitable for carrying out the test. Fineness test: To measure fineness of the fibre, samples were inserted through a 6 inches length sample holder tightly and the elongated fibres were cut at the edge of the sample holder by a cutting machine. Then weighed as $54.2 \mathrm{~g}$ and again inserted into a 3 inches length sample holder. After cutting the elongated fibres from both ends of the holder, it was used to measure fibre fineness and then again weighed and calculated the actual fineness.

\subsection{Chemical Parameters}

Chemical parameters were taken on the basis of moisture correction it was very much essential to estimate correct results. Percentage of moisture content was determined by standard method [15]. Pectin content was determined by boiling the sample with oxalic acid and ammonium oxalate solution. Fatty/oily materials were extracted from jute seed and jute fibre with petroleum ether in a soxhletapparatus[16]. The content of alpha cellulose and hemicellulose was determined by the TAPPI method. Lignin content was determined by the TAPPI sulphuric acid standard method [17]. Ash content was determined by ashing the sample in Muffle furnace in a porcelain crucible according to a standard method [18].

\subsection{Bleaching Treatment Was Done by the Following Way}

(1) Scouring has been carried out by heating jute sample at 80-900C with 8-10 g/l sodium carbonate solution containing slight amount of wetting agent for half an hour.

(2) Bleaching was done with hydrogen peroxide by using Hydrogen peroxide $=6 \%$ on the weightof jute sample. Sodium silicate $=3 \%$, Sodium carbonate $=3 \%$, Wetting agent $=0.1 \%, \mathrm{PH}=10-11$. Time $=$ one hour, Temperature $=\mathrm{Up}$ to boiling after $\mathrm{b}$ leaching treatment jute sample waswashed and air dried.

\section{Results and Discussions}

Result of some physico-chemical properties of variety $\mathrm{O}$ 72 in comparison with O-9897 jute sampleswere summarized in the table 1 , table 2 and table 3.

Table 1. Physical parameter of O-72 variety and $0-9897$ jute samples.

\begin{tabular}{llll}
\hline \multirow{2}{*}{ Physical parameters } & \multicolumn{3}{l}{ Types of jute sample } \\
\cline { 2 - 4 } & $\begin{array}{l}\text { Jute variety } \\
\text { O-72 }\end{array}$ & $\begin{array}{l}\mathbf{6 \%} \mathbf{H}_{\mathbf{2}} \mathbf{O}_{2} \\
\text { Bleached }\end{array}$ & $\begin{array}{l}\text { Jute variety } \\
\text { O-9897 }\end{array}$ \\
\hline Reed jute fibre length (meter) & $3-3.5$ & - & $03-3.5$ \\
Brightness index (\%) & 22.04 & 44.62 & 21.50 \\
Whiteness index (\%) & 35.63 & 45.79 & 17.31 \\
Bundle strength (Kg/mg.) & 06.20 & 04.31 & 04.95 \\
Fineness (micron) & 36.26 & - & 35.39 \\
\hline
\end{tabular}

Reed jute fibre length of O-72 variety was found to be 3$3.5 \mathrm{~m}$ which was same values as $0-9897$ variety jute samples. In table 1, brightness index of O-72was observed higher than that of the O-9897jute fibre and more or less same as like as $6 \% \mathrm{H}_{2} \mathrm{O}_{2}$ bleached sample. Bundle strength of jute fibreis another important physical parameter. After bleaching, about $12 \%$ bundle strength was deterioratedthan unbleached sample. Variety O-72 was not affected to loss bundle strength like bleached jute samples, on the other hand having higher brightness index without bleaching. Fineness parameter of jute variety O-72 is also nearly to O-9897 jute samples.

Table 2. Major chemical constituents of new variety jute sample O-72 in comparison with O-9897 jute samples.

\begin{tabular}{llll}
\hline Name of samples & Cellulose (\%) & Hemicellulose (\%) & Lignin (\%) \\
\hline Jute fibre O-72 & 65.68 & 17.94 \\
Bleached jute samples $\left(6 \% \mathrm{H}_{2} \mathrm{O}_{2}\right)$ & 64.29 & 17.47 \\
Jute Fibre O-9897 & 63.24 & 18.47 & 13.56 \\
\hline
\end{tabular}

From table 2, it was found that major chemical constituents in new variety O-72 indicated a good

quality jute fibre owing to higher percentage of cellulose content with lower percentage of lignin and hemicellulose than that of normal jute fibre. Another significant indication is $6 \% \mathrm{H}_{2} \mathrm{O}_{2}$ bleached jute sample showed nearly about same value on the lignin and hemicellulose content (on the basis of bleached sample) like unbleached fibre. 
Table 3. Minor chemical constituents present in O-72 and O-9897 jute samples.

\begin{tabular}{llllll}
\hline Name of samples & Pectin content (\%) & Fat/Oil content(\%) & Ash content (\%) & Oil content in juteseed (\%) & Saponificationvalue \\
\hline O-72 & 0.21 & 0.87 & 0.67 & 8.109 & 232.27 \\
O-9897 & 0.20 & 0.50 & 0.80 & 10.94 & 212.72 \\
\hline
\end{tabular}

Minor chemical constituents were shown in table 3, oil content in jute seed of O-72 was found lower than that of conventional O-9897 jute seed but oil percentage is higher in jute fibre $\mathrm{O}-72$ as well as saponification value. Higher percentage of oil content in any textile fibre is helpful for spinning which acts as a softener and lubricating agent. Lower content of ash also supports the quality jute fibre like O- 72. By chemical analysis of blue jute seed O-72, extracted oil content showed higher percentage of saponificattion value having lower percentage of oil content than conventional jute fibre. On the overall survey it may be concluded that the new variety O-72 jute fibre would be very helpful/useful as cost effective raw materials for diversified end uses of jute fibre.

\section{Conclusion}

The present study focused on the physico-chemical properties of newly released jute variety O-72. From the result it is clear that physical parameters of O-72 fibre have been found better quality in regards of strength, fineness and whiteness. On the other hand chemical properties is also an important factor for jute fibre where alpha cellulose is the most important chemical constituent which was higher in the O-72 fibre than other types of jute fibre. From the overall discussion it can be concluded that the variety of O-72 fibre is superior (i.e. better quality) considering the good looking and maximum amount of fibrous materials which are most important in the field of diversified uses of jute fibre.

\section{References}

[1] Abdullah, A. B. M. 1978. Preparation of Microcrystalline cellulose from Jute. Bangladesh J. Jute Fib. Res. 3: 39-43.

[2] Amin, M. N., M. Begum and M. Shajahan. 1993. A Process of Bleaching of Jute Fabric. Bangladesh J. Sci. Ind. Res. 27: 80.

[3] Kirby, R. H. 1963. Vegetable fibres. New York: Interscience publishers.

[4] Preston, R. D. 1974. The physical biology of plant cell walls. London: Chapman and Hall.

[5] Grabber, J. H., G. A. Jung and R. R. Hill. 1991, Chemical composition of parenchyma and sclerenchyma cell walls isolated from orchard grass and switch grass. Crop Science 31: 1058-1065.

[6] Lewis, N. G. and L. B. Davin.1994. Evolution of lignan and neolignin biochemical pathways. In. Nes D. ed. Evolution of natural products, ACS Symposium Series. Washington, DC: American Crop Society, 202- 246.

[7] Kundu, B. C. 1944. Anatomy of jute stem with special reference to cambial activity and distribution of fibres in relation to leaf-trace system. Journal of Royal Asiatic Society, Bengal (Science) 10:27-52.

[8] Fahn, A. 1990. Plant anatomy, 4th edn. Oxford: Pergamon Press.

[9] Urquhart, A. R. and F. O. Howitt. 1953. The structure of textile fibres. Manchester: Textile Institute.

[10] Gorshkova, T. A., V. V. Salnikov, N. M. Pogodina, A. B. N. Chemikosova, E. V. Yablokova, A. V. Ulanov, M.V. Ageeva, J. E. G. Vandam and V. V. Lozovaya. 2000. Composition and distribution of cell wall compounds in flax (Linumusitatissimum L.) stem tissues. Annals of Botany, 85: 477-486.

[11] Amin, M. N, M. Shajahan, M. Begum, M. S. Rahman, T. Boksh. K. A. Rahman and M. Kamal Uddin. 1996.Manual for bleached and softened Jute/Kenaf fabrics for application in upholstery, Volume II, International Jute Study Group (IJSG), Dhaka.

[12] Bashiruzzaman. 1964. The Chemical Constituents and Molecular Weight of Cellulose in Different Parts of Jute. J. Tex. Ins., 4: 910-911.

[13] Macmillan, W. G. 1957. Jute and Jute Research. Jute-The Golden Fibre. 1st Edition, P. 147.

[14] Sen Gupta, B. A. Majumder and K. Sachindra. 1970. 1989044 (cl, D 060), 13 (24 April).

[15] Panto, J. and K. B. Francis. 1969. US 3472609 (cl-8-111), 3, (14 October).

[16] Kulkarni, A. Y. and T. K. G. Roy. 1973. Bleaching of Jute with sodium Chlorite. Jute. Tex. Asso., 3: 59-62.

[17] Timell, T. E. 1957. TAPPI, 40, 568. TAPPI. Standard Method, T $22 \mathrm{~m}-52$.

[18] Khuda, M. M., A. S. M. Serajuddin, N. Amin and A. A. Khan. 1976. Determination of cellulose in different grades of jute. Pakistan J. Sci. Ind. Res., 11: 51-52. 